\title{
Cytokinins Affect Respiration, Ethylene Production, and Chlorophyll Retention of Packaged Broccoli Florets
}

\author{
James W. Rushing \\ Coastal Research and Education Center, Clemson University, 2865 \\ Savannah Highway, Charleston, SC 29414
}

Additional index words. Brassica oleracea var. italica, benzyladenine, zeatin

\begin{abstract}
Broccoli (Brassica oleracea L. var. italica 'Citation') florets were treated postharvest with either benzyladenine or trans-zeatin at either 10 or $50 \mathrm{ppm}$ before packaging in perforated polyethylene bags and storage at $16 \mathrm{C}$. The most pronounced effects were observed with benzyladenine at $50 \mathrm{ppm}$. Compared to controls, respiration rate was reduced $50 \%$ and ethylene production increased $40 \%$ throughout the first 4 days of storage. Total chlorophyll content had dropped $60 \%$ in controls, but was unchanged in cytokinin-treated florets, which had a $90 \%$ longer shelf life than controls. These effects depended on the amount of cytokinin applied and were of greater magnitude with benzyladenine than with zeatin.
\end{abstract}

The demand for fresh, pre-packaged, readyto-eat vegetable products has increased as more members of households work and less time is available for food preparation (Zind, 1988). Pre-packaged broccoli florets are popular with many customers. The modified atmosphere (MA) packaging of broccoli to delay senescence has met with some success (Ballantine et al., 1988) and MA has been shown to be potentially useful by Lieberman and Hardenburg (1954), Lieberman (1955), and by Lipton and Harris (1974); however, supplemental methods of extending shelf life are desirable because of the product's high perishability. Postharvest application of cytokinins has been shown to delay senescence of whole stalks of broccoli (Dedolph et al., 1963; Dostal et al., 1976; Gilbart and Dedolph, 1965; Shewfelt et al., 1983). In some cases, preharvest treatments were effective, but the results were generally more variable (MacLean et al., 1963; Rushing, 1987; unpublished data). The extension of storage potential in Cytokinin-treated tissues has been attributed to their lower respiration rates relative to controls (Gilbart and Dedolph, 1965; MacLean et al., 1963).

Compared to whole stalks, broccoli florets appear to represent a different set of physiological conditions because of the large relative increase in cut surface. In response to such wounding, plant tissues generally exhibit an increase in the rates of both respiration and ethylene production (Kader, 1987). Exposure to low levels of ethylene, e.g., $\leq 1$ ppm, is known to accelerate chlorophyll

Received for publication 21 Nov. 1988. Technical Contribution no. 2907 of the South Carolina Agricultural Experiment Station. The technical assistance of Gary LaMunion and Selena Barfield is gratefully acknowledged. This work was funded in part with a grant from Abbott Laboratories. The cost of publishing this paper was defrayed in part by the payment of page charges. Under postal regulations, this paper therefore must be hereby marked advertisement solely to indicate this fact. degradation and other features of senescence (Watada, 1986). It is unknown if cytokinins can extend the postharvest life of partially processed broccoli. This report describes the -effects of two different cytokinins, each applied postharvest at two rates, on respiration, ethylene production, chlorophyll retention, and shelf life of prepackaged broccoli florets.

Broccoli plants were grown at the Coastal Research and Education Center, Charleston, S. C., in Spring 1987 according to standard commercial practices. Whole stalks were harvested before 9:00 AM and immediately transported to a refrigerated (16C) work area. Stalks were surface-sterilized by dipping for 2 min in $100 \mathrm{ppm} \mathrm{NaOCl}$ followed by two rinses with tap water containing $2 \mathrm{ppm}$ $\mathrm{NaOCl}$. Florets were trimmed from the stalks by hand with a sterile, sharp knife.

Treatments included a water control and the cytokinins 6-benzyladenine and transzeatin (Abbott Laboratories) applied at either 10 or $50 \mathrm{ppm}$. Florets were dipped in the appropriate treatment solution (16C) for 1 rein, removed, and allowed to drain for $\approx 15$ min before being packaged.

After treatment, florets were packaged (100 $\mathrm{g} / \mathrm{bag}$ ) in 1.75-roil polyethylene bags with four perforations $(0.5 \mathrm{~cm}$ in diameter $)$ per bag. Packages were stored at $16 \mathrm{C}$ in darkness except for the brief periods of light needed for daily quality examination and gas analysis. This temperature was the worst situation found in a survey of local retail produce displays. Florets were evaluated for yellowing, flower opening, and presence of undesirable odors. Six packages were stored from each treatment and the experiment was repeated twice.

Other florets were placed in glass jars equipped with rubber septa and stored at $16 \mathrm{C}$ partially uncovered, except for the times gas measurements were needed. Each day, jars were sealed for $30 \mathrm{~min}$ and 1-ml gas samples withdrawn from the headspace for GC analysis of $\mathrm{CO}_{2}$ and $\mathrm{C}_{2} \mathrm{H}_{4}$.
At selected intervals, florets were removed from packaged samples and frozen for subsequent determination of total chlorophyll and chlorophyll $a$ and $b$ contents by using the dimethylformamide method (Moran and Porath, 1980; Moran, 1982).

Separate experiments were conducted to determine the effects of processing on woundinduced respiration and ethylene production. Rates were measured on 12 freshly harvested stalks of broccoli, then one-half of the stalks were processed into florets and rates measured for all material at selected intervals for $24 \mathrm{hr}$. The experiment was repeated once.

Processing of florets caused a wound-induced increase in the rates of both respiration and ethylene production compared to whole stalks. The maximum difference in respiration was observed $\approx 6 \mathrm{hr}$ after processing and was $38 \%$ higher in florets than-intact stalks. The maximum difference in ethylene production was $30.5 \%$ and occurred $\approx 12 \mathrm{hr}$ after processing. Within $24 \mathrm{hr}$, the rates of both respiration and ethylene production were nearly identical in all samples (data not shown).

The initial measurement of respiration for the cytokinin experiment was conducted $\approx 3$ $\mathrm{hr}$ after processing, at which time all samples were respiring rapidly; i.e., $\geq 200 \mathrm{ml} \mathrm{CO}_{2} /$ $\mathrm{kg}$ per hr (Fig. 1A). Within $24 \mathrm{hr}$, the rate in all treatments had decreased to $\approx 50 \%$ of the initial level. By day 2 the respiration rate of controls had risen to $\approx 130 \mathrm{ml} \mathrm{CO} / \mathrm{kg}$ per $\mathrm{hr}$, while the rate of all cytokinin-treated tissues had continued to decrease slightly. On day 3 , the rate in florets treated with zeatin had risen to near the rate in controls and did not differ from controls throughout the remainder of the storage period. Florets that were treated with $13 \mathrm{~A}$ senesced without exhibiting the rise in respiration that was evident in controls and zeatin-treated samples (Fig. 1A). The effects of cytokinins on respiration of broccoli florets are similar to earlier work with whole stalks in which the rate was depressed following treatment (Gilbart and Dedolph, 1965; MacLean et al., 1963). Similar postharvest effects of cytokinins on respiration have been reported for a number of commodities (Dedolph et al., 1963; Wittwer et al., 1962).

Ethylene production of all samples initially was in the range of 5 to $6 \mathrm{nl} \cdot \mathrm{g}^{-1} \cdot \mathrm{hr}^{-1}$ (Fig. 1B). The rate in controls increased only slightly to a peak on day 2 , then gradually decreased to $\approx 4.5 \mathrm{nl} \cdot \mathrm{g}^{-1} \cdot \mathrm{hr}^{-1}$ by the 4 th day. Zeatin-treated samples exhibited an increase in ethylene production that peaked on day 2 , then dropped to control levels by day 4 . The amount of zeatin applied did not appear to significantly affect the amount of ethylene produced (data not shown). Peak ethylene production in both zeatin and BA treatments occurred at about the same time; however, florets treated with BA exhibited a more dramatic rise in ethylene production than was observed with zeatin treatment (Fig. 1B). At the peak, samples treated with $10 \mathrm{ppm} \mathrm{BA}$ were producing $\approx 8.2 \mathrm{nl} \cdot \mathrm{g}^{-1} \cdot \mathrm{hr}^{-1}$ compared to 9.4 for those treated with $50 \mathrm{ppm}$. By day 4 , ethylene production in all cytokinin-treated 

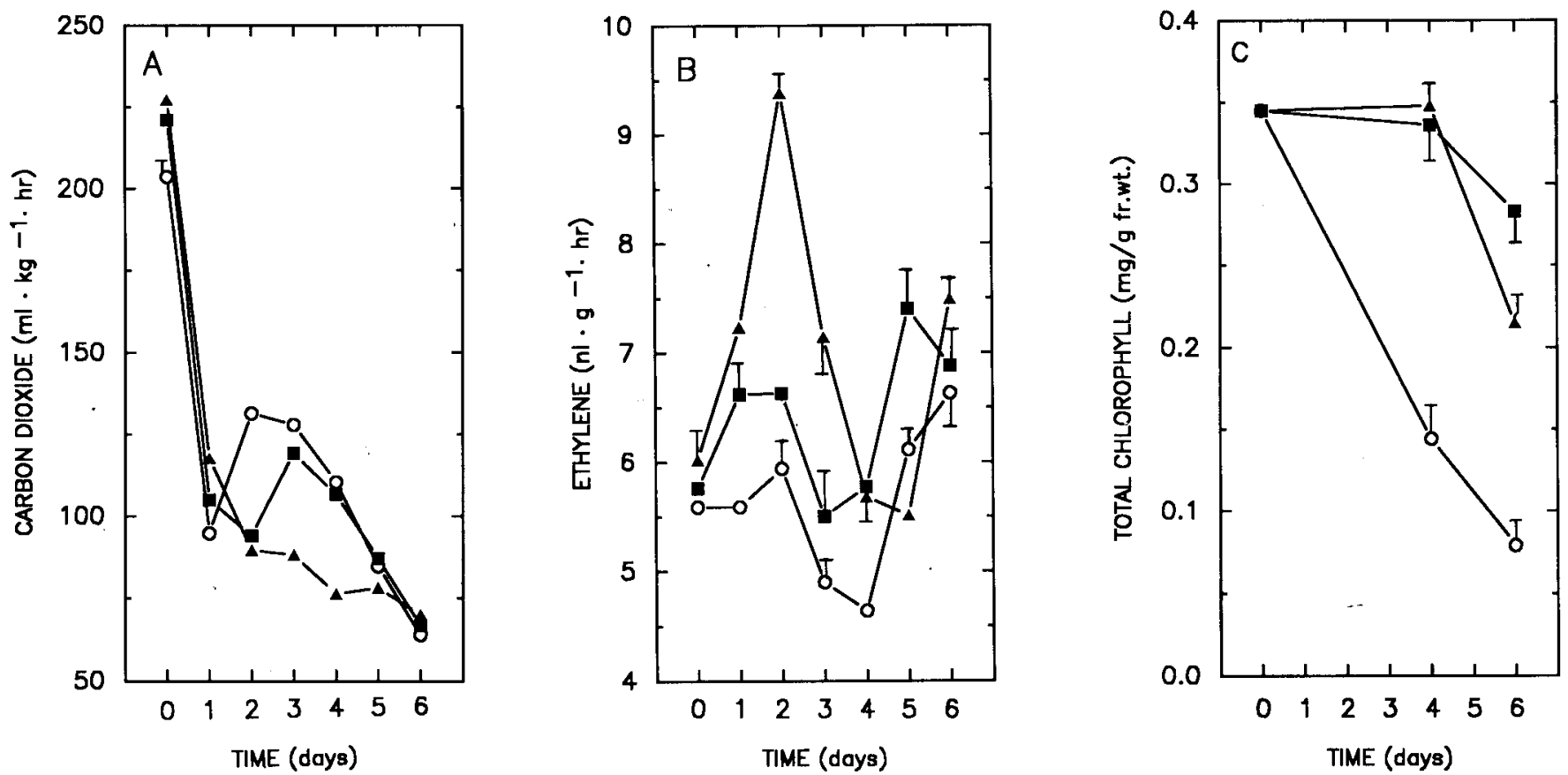

Fig. 1. Effect of benzyladenine (BA) and zeatin treatments on (A) the respiration rate, (B) ethylene production, and (C) total chlorophyll content of broccoli florets at $16 \mathrm{C}$. Each point on the graphs represents the mean of 'six measurements and the experiment was conducted twice with similar results each time. Bars represent SE, and, when absent, fall under the symbol ( $\bigcirc=$ control, $\boldsymbol{\Delta}=50 \mathrm{ppm} \mathrm{BA}, \boldsymbol{\square}=50 \mathrm{ppm}$ zeatin).

tissues had dropped to near the initial level. In the final 2 to 3 days of storage, all samples produced increasing amounts of ethylene as" senescence advanced. This increase in ethylene production following cytokinin treatment (Fig. 1B) has also been reported for mung bean (Lau and Yang, 1976). In early packaging work with broccoli, ethylene accumulation was believed to be the cause of yellowing and flower opening (Lieberman, 1955). This result, plus the fact that off-odors can develop in sealed packages (Lieberman and Hardenburg, 1954), suggests that the use of plant growth regulators may be a more viable approach to extending shelf life than MA packaging if the chemicals were approved for such use. Bags used in this study were vented and daily analysis of air samples confirmed that the ethylene concentration never reached $30 \mathrm{ppb}$, the lowest detectable limit of our equipment. Objectionable odors were not detected until after yellowing and flower opening were advanced.

The total chlorophyll content of all samples on the day of harvest was $\approx 0.35 \mathrm{mg} \cdot \mathrm{g}^{-1}$ fresh weight (Fig. 1C). By day 4, the total chlorophyll content of controls had decreased more than $50 \%$ and the florets were considered unmarketable. Samples that were treated with $10 \mathrm{ppm}$ of either BA or zeatin had lost $\approx 15 \%$ of their chlorophyll by day 4 (data not shown); however, tissues treated with $50 \mathrm{ppm}$ of either compound had no significant decrease below the initial level by day 4. Chlorophyll degradation was apparent in all samples between days 4 and 6 (Fig. 1C). The trends described for total chlorophyll content generally were evident for chlorophyll $a$ and $b$ (data not shown).

Florets were categorized marketable or unmarketable based on yellowing and flower opening. Control samples deteriorated rap- idly and became unmarketable between days 3 and 4. Samples with $10 \mathrm{ppm}$ zeatin deteriorated at a rate similar to the control samples. Florets with 10 ppm BA or 50 ppm zeatin were unmarketable on day 6 , while those with 50 ppm BA were still marketable. Slight browning on cut surfaces was noted in all samples, but yellowing and flower opening were the main reasons for quality loss.

Greater effectiveness of BA over zeatin in retarding senescence has also been reported with soybeans by Garrison et al. (1984), who suggested that zeatin was metabolized more rapidly than BA.

The ultimate test of a postharvest treatment is consumer acceptance. In earlier work by Dedolph et al. (1963), taste panelists preferred cytokinin-treated broccoli over controls when they saw the samples before consumption, demonstrating that their judgment was biased by the effectiveness of cytokinin in retaining chlorophyll. This effect was quantified by Shewfelt et al. (1983) with intact heads and by me with florets (Fig. 1C).

The results presented here confirm that postharvest cytokinin treatment has potential for extending the marketable life of prepackaged broccoli florets in spite of the wounding inflicted during processing. However, neither compound has been officially approved for such use. The apparent contradictory effects of cytokinins, i.e., decreased respiration and increased ethylene production, merit further investigation.

\section{Literature Cited}

Ballantine, A., R. Stark, and J.D. Selmon. 1988. Modified atmosphere packaging of broccoli florets. Intl. J. Food Sci. Technol. 23:353-360.
Dedolph, R. R., S.H. Wittwer, and H.E. Larzelere. 1963. Consumer verification of quality maintenance induced by $\mathrm{N}^{6}$-benzyladenine in the storage of celery (Apium graveolens) and broccoli (Brassica oleracea var. Italica). Food Technol. 17:111-112.

Dostal, H. C., R.R. Dedolph, and V. Tuli. 1965. Changes in nonvolatile organic acid constituents in broccoli (Brassica oleracea var. Italica) following postharvest $\mathrm{N}^{6}$-benzyladenine treatment. Proc. Amer. Soc. Hort. Sci. 86:387-391.

Garrison, F. R., A.M. Brinker, and L.D. Nooden. 1984. Relative activities of xylem-supplied cytokinins in retarding soybean leaf senescence and sustaining pod development. Plant Cell Physiol. 25:213-224.

Gilbert, D.A. and R.R. Dedolph. 1965. Phytokinin effects on respiration and photosynthesis in roses and broccoli. Proc. Amer. Soc. Hort. Sci. 86:774-778.

Kader, A.A. 1987. Respiration and gas exchange of vegetables, p. 25-43. In: J. Weichmann (cd.). Postharvest physiology of vegetables. Marcel Dekker, New York.

Lau, O. and S.F. Yang. 1976. Stimulation of ethylene production in the mung bean hypocotyls by cupric ion, calcium ion, and kinetin. Plant Physiol. 57:88-92.

Liebcrman, M. and R.E. Hardenburg. 1954. Effect of modified atmospheres on respiration and yellowing of broccoli at 75 degrees F. Proc. Amer. Soc. Hort. Sci. 63:409-414.

Lieberman, M. 1955. Oxygen tension in relation to volatile production in broccoli. Proc. Amer. Soc. Hort. Sci. 65:381-386.

Lipton, W.J. and C.M. Harris. 1974. Controlled atmosphere effects on the market quality of stored broccoli (Brassica oleracea L., Italica group). J. Amer. Soc. Hort. Sci. 99:200-205.

McLean, D. C., R.R. Dedolph, and S.H. Wittwer. 1963. Respiratory responses of broccoli (Bras- . sica oleracea var. Italica) to pre- and post-harvest treatments with $\mathrm{N}^{6}$-benzyladenine. Proc. Amer. Soc. Hort. Sci. 83:484-487.

Moran, R. and D. Porath. 1980. Chlorophyll de- 
termination in intact tissues using N,N-dimethylformamide. Plant Physiol. 65:478-479.

Moran, R. 1982. Formulae for determination of chlorophyllous pigments extracted with N, N-dimethylformamide. Plant Physiol. 69:1376-1381. Shewfelt, R. L., K.M. Batal, and E.K. Heaton. 1983. Broccoli storage: Effect of $\mathrm{N}^{6}$-benzyl- adenine, packaging, and icing on color of fresh broccoli. J. Food Sci. 48:1594-1597.

Watada, A.E. 1986. Effects of ethylene on the quality of fruits and vegetables. Food Technol. 40:82-85

Wittwer, S. H., R.R. Dedolph, V. Tuli, and D. Gilbart. 1962. Respiration and storage deterio- ration in celery (Apium graveolens L.) as affected by postharvest treatments with N'benzylaminoprrrine. Proc. Amer. Soc. Hort. Sci. 80:408416.

Zind, T. 1988. A profile of fresh produce consumers. The Packer Focus, p. 42-45. Vance Publishing, Overland Park, Kan.
HORTSCIENCE 25(1):90-92. 1990.

\section{Silver Thiosulfate Prevents Ethylene- induced Abscission in Holly and Mistletoe}

\author{
Daryl C. Joyce, Michael S. Reid, and Richard Y. Evans \\ Department of Environmental Horticulture, University of California, \\ Davis, CA 95616
}

Additional index words. holly, Ilex spp., mistletoe, Phoradendron tomentosum, ethylene, silver ion

\begin{abstract}
Low concentrations of ethylene induced abscission of leaves and berries from cut branchlets of English holly (Ilex aquifolium L.) and American mistletoe [Phoradendron tomentosum (DC.) Engelm. ex Gray ssp. macrophyllum (Engelm.) Wiens]. Application of $1 \mu \mathrm{mol}$ of $\mathrm{Ag}^{+}$per branchlet (as the anionic silver thiosulfate complex, STS) via the transpiration stream was found to retard this abscission. A higher application rate $\left(4 \mu \mathrm{mol} \mathrm{Ag}^{+}\right.$per branchlet) stimulated leaf abscission in mistletoe. There were marked differences in sensitivity to ethylene among various types of holly.
\end{abstract}

Holly and mistletoe are used traditionally for decoration during the Christmas season. Both are, however, prone to leaf and berry abscission during transport and marketing. This renders them unattractive and limits full realization of their aesthetic and commercial potential. Commercial holly producers presently treat the harvested branches with naphthalene acetic acid (NAA) to reduce abscission of leaves and berries during marketing (Roberts and Ticknor, 1970), but this procedure has been observed to be only partially effective (P. Schmidt, personal communication).

Abscission of plant organs is a frequent response to the presence of elevated levels of $\mathrm{C}_{2} \mathrm{H}_{4}$ (Reid, 1985) that may accumulate in the atmosphere surrounding harvested produce as a result of endogenous $\mathrm{C}_{2} \mathrm{H}_{4}$ production or as" a consequence of air pollution (Sherman, 1985). In holly, infection of branches with Phytophthora ilici aggravates organ abscission, apparently because the pathogen induces $\mathrm{C}_{2} \mathrm{H}_{4}$ production by the plant (D. Coyier, personal communication).

The inhibition of $\mathrm{C}_{2} \mathrm{H}_{4}$ action by silver ion $\left(\mathrm{Ag}^{+}\right)$(Beyer, 1976a, 1976b) has been used as a practical tool to increase the longevity of some cut-flower species (Mor et al., 1984a, 1984b; Veen and van de Geijn, 1978) and

Received for publication 26 May 1988. This work was supported in part by Binational Agricultural Research and Development Award no. 1-250-82. The cost of publishing this paper was defrayed in part by the payment of page charges. Under postal regulations, this paper therefore must be hereby marked advertisement solely to indicate this fact. aquifolium L. (English holly), I. cornuta Lindl. (Chinese holly), I. cornuta cv. Burfordii (Burford holly), I. × altaclarensis Wilsonii, (Wilson holly), and I. vomitorii Ait. cv. Nana (dwarf Yaupon holly). In one experiment, we compared branchlets from spiny and spineless plants of Burford holly. The mean numbers of leaves on the 15- to $20-\mathrm{cm}$ branchlets were seven for mistletoe and 11 for holly.

The experiments examined the ethylene response of the different Christmas greens, and the effect on the quality of control and ethylene-treated branchlets of pulsing with STS or treatment with a cut-flower preservative. In all but one experiment, branchlets were placed in 10-ml glass test tubes containing deionized water (DI) or $4 \%(\mathrm{w} / \mathrm{v}) \mathrm{su}$ crose plus 200 ppm Physan 20 (a mixture of quaternary $\mathrm{NH}_{4}^{+}$compounds) in DI. In the other experiment, mistletoe branchlets were placed in the $10 \times 20-\mathrm{cm}$ perforated plastic bags used commercially for marketing mistletoe branchlets. Each bag had twenty-four 6-mm-diameter holes. Three branchlets were placed in each bag, and solutions were supplied to the cut stem ends in presoaked cotton balls. The solutions were $1 \%(\mathrm{w} / \mathrm{v})$ Floralife (a commercial flower preservative) and 0.4 or $4 \mathrm{mmSTS}$ in $1 \%$ (w/v) Floralife. STS was prepared as described by Reid and Farnham (1980).

For experiments when STS was supplied as a pulse taken up via the transpiration stream, the uptake of $\mathrm{Ag}^{+}$was measured by weighing the uptake vial (which contained $10 \mathrm{~mm}$ STS). A 0.1-g decrease in weight was taken to indicate uptake of $1 \mu \mathrm{mol} \mathrm{Ag}^{+}$. 